\title{
KOMMENTEERIDA VÕI MITTE?
}

Mälestused - ja nendega haakuvad nn elulooraamatud - tunnukse olevat nii avaldajate kui ka lugejate eelistuste esirinnas. Mälestusi ilmub sarjadena näiteks monumentaalne sari „Eesti mälu" -, omaette teostena, aga samuti kildudena asutuste, organisatsioonide, koolide ja muude üksuste juubeliväljaannetes. Olgu siin näitena mainitud „Pärnu Ühisgümnaasium. Algusest aastani 1952” (Tallinn, 2006), mille 784 leheküljest kaugelt üle poole hõlmavad mälestused.

On vististi loomulik, et huvitutakse eeskätt omainimeste - eestlaste ja eestimaalaste - mälestustest. Neist loodetakse tuttavate inimeste või tuntud asjaolude nägemist erinevast vaatepunktist. Väga sageli loodetu täitubki: Eesti on ju väike ja paljud tunnevad paljusid. Nii leidsin Harri Jõgisalu mälestustest „Märjamaalt Tallinna ja kaugemale" (Tartu: Ilmamaa, 2011) terve peatüki kursusekaaslasest Leonhard Vaidest. Ent omamaise eelistamine ei välista sugugi võõraid memuaare. Tuntud ja mõjukate inimeste mälestused pakuvad ikka huvi. Mäletan omaaegse sarja „Marseljeesist Internatsionaalini” menukust 1930. aastail. Memuaaride loetavus sõltub mõistagi suuresti sõnastajast - nii sõnaseadmise oskusest kui ka taustateadmiste vahendamisest. Kui kirjutaja viimasest suurt ei hooli, on lugejale tavaliselt abiks tõlkija või toimetaja kommentaarid kas järelsõnana või joonealuste märkustena. Siin võiks heaks eeskujuks olla „Eesti mälu” sarjas ilmunud Eduard von Dellingshauseni mälestused „Kodumaa teenistuses. Eestimaa Rüütelkonna peamehe mälestused" (Tallinn: Eesti Päevaleht, 2011). Kuigi tegu on ikkagi omainimesega, kes vahendab meie oma ajalugu ehkki teisest vaatenurgast -, on seal kommentaare peaaegu igal teisel leheküljel.

Kui mälestuste autor esindab riiki, mille ajalugu tuntakse vähe, halvasti või üldse mitte, siis on kommentaarium eriti vajalik. Mälestused tegelevad enamasti n-ö mikroajalooga, kui tegemist pole just riigimehe või rahvajuhiga. Just seda tunneme me eriti teiste rahvaste puhul vähe või ei tunne üldse.

Ei oska öelda, kui palju meil tuntakse poola nobelisti Czesław Miłoszit. Sestap võtsin teatava ootusliku rõõmuga lugeda tema mälestused „ABC". Teos ehmatas. Autor ei ole mälestusi esitanud mitte kronoloogiliselt, vaid isikute, kohtade, nähtuste kaupa alfabeetiliselt (sellest ka pealkiri). Mälestused on esitatud kildudena, lühiesseedena. Kuigi ülevaade jääb lünklikuks, ilmneb kildudestki, et tegu oli huvitava inimese ja oluliste lugudega. Muidugi peaksime Euroopa suurriigi - seda ju Poola on ajaloost rohkem teadma. Küllap tõlkija teabki. Imestan väga, et kirjastaja Hendrik Lindepuu ei nõudnud tõlkija Hendrik Lindepuult vajalikke kommentaare. Küsimusi tekib hulgi (nt Vilniuse grupp lk 75, Vagabundi klubi, Dembinsky grupp lk 254, filomaat lk 257 , G. R. Noyes lk 276, vastupanuorganisatsioon Vabadus lk 280 jpt) - vastuseid aga pole. Mõistagi on seesuguste kildude seostamine kommentaaride abil üsnagi keeruline, kuid ometi mitte võimatu.

Lugupeetud kirjastajad, toimetajad ja tõlkijad, uskuge mind, kommentaare 
on alati vaja. Kergem on andestada ülekommenteerimist kui kommentaaride puudumist. Kommentaarium aitab teksti mõista. Loetu mõistmine elavdab kindlasti ka käivet, nii teose ostmist kui ka laenamist. Seega peaks kirjastus kommentaaridest huvituma, mitte neid põlgama. Mõistagi peaks kommentaar ulatuma enesestmõistetavusest sügavamale. Väheütlev on nending: see ja see on kirjanik. Tahame teada, kas ja kuidas ta on mõjutanud memuaristi või oli tegu juhusliku külaskäiguga. Teadagi pole heade kommentaaride koostamine kerge töö. Sestap jõudu selle vaevarikka, ent olulise töö tegijatele.
Muide, tunases vabariigis oli kombeks raamatu lõpus vahendada ka nimede hääldus. See tava püsis ka okupatsiooni esimestel aastakümnetel, kuid hääbus pikkamööda. Kui loobuksime harjumusest pidada ennast kõiketeadjaks, siis oleks seegi vana komme teretulnud (eriti sellise keeruka kirjapildiga keele puhul, nagu seda on poola keel). Ja eks ole seegi üks kommenteerimise vorme - ta ju aitab lugejat. 